\title{
Mobile Texts and Local Options: Geography and Editing
}

\author{
H. Wayne Storey
}

\begin{abstract}
The seeming opposition between local and mobile texts has guided, in sometimes inadvertent ways, our methods for editing works often defined by the notion of fixity-of lectiones and/ or material structures - or its absence. This essay investigates two examples of the interplay between remarkably fixed local options and the mobility of textual transmission: Raimbaut de Vaqueiras's parodic, bilingual debate poem Domna, tant vos ai preiada and Francesco Petrarca's ballata Donna mi vene spesso ne la mente and his madrigal Or vedi, Amor, che giovenetta donna, both of which are emblematic of compositional and compilational strategies in the Rerum vulgarium fragmenta.
\end{abstract}

\section{$\mathrm{O}$} PPOSITIONAL DEFINITIONS OFTEN ESTABLISH DYNAMICS UPON which we build our seemingly most careful editorial arguments. The local variants of works composed more for performance than a "written tradition", for example, have often proved problematic for neo-Lachmannian stemmatics designed to arrive at an authorized text. One of these oppositions hinges on the seemingly diverse roles of geography and mobility in texts. ${ }^{1}$ Geography — of course - plays a critical part in our assessments of a work's linguistic patina, as well as of the material and intellectual roads across diverse territories along which copies of the work are transmitted. We tend not only to distinguish between the "geographical stability" and the "unstable mobility" of some witnesses, assessments sometimes based more on traditions than the actual evidence of linguistic layers present in the copy, but even to alter readings found in authoritative witnesses in order to conform the text to historical interpretations. The earliest transmission of the sonnet No me poriano zamay fare menda (in 1287) with linguistic, prosodic, material, and thematic characteristics geographically assignable to Bologna became rationales for scholars to conjecture Dante's

1. See Swan 2007 and especially Wendy Scase's brief discussion (2007) of this opposition of seeming geographic fixity and textual mobility, and its pivotal role in diverse medieval traditions of the English West Midlands. 
early stay in Bologna in order to match the sonnet's attribution to him in a later and revered manuscript produced in mid-fourteenth-century Florence. ${ }^{2}$ And when we reflect upon the fact that well over half of the surviving chansonniers of Old Occitan poetry performed at the eleventh- and twelfth-century courts of southern France were copied in northern Italy between the mid-thirteenth and the seventeenth centuries, we see even more clearly the complex roles of geography and mobility in the transmission of textual cultures. ${ }^{3}$ On the one hand it would be unthinkable to dismiss this sizeable corpus as "out of country", especially in light of the continuing production of lyrics in Old Occitan by the earliest Italian poets in purely Italian contexts, such as the Venetian Bartolomeo Zorzi and the Genoese Lanfranco Cigala and Percivalle Doria, all poets active in the mid- to late thirteenth century. At the same time, as Carlo Pulsoni (2004, 371-8) has noted, the editorial treatment of occurrences of Old Occitan in works such as Dante's Commedia or his unfinished treatise on language and style, the De vulgari eloquentia, reveals a modern editorial willingness to dismiss questions of the competence of early copyists in Old Occitan and even readings from legitimate witnesses in favor of a sanitized, modern knowledge of Old Occitan forms. Pulsoni's point is that, unlike our editions of the De vulgari eloquentia or even Purgatorio 26, Dante's knowledge of Old Occitan was probably not perfect $(2004,375-6)$, and that of many of his copyists even less so, especially those grappling with antegraphs of his unfinished and unrevised De vulgari eloquentia from which they were making their own copies.

To these equations of "local variants" we must also add a dimension seldom considered, and yet its impact is significant: the local variants of support materials themselves in the production of copies. From local practices for gatherings of bifolia into booklets to local uses of scripts and qualities of parchment prepared for copies, geographical traditions of the

2. The earliest extant copy of the sonnet is found in the civic registers of the Memoriali bolognesi, on c. 203v of vol. 69 (1287). The later, Tuscan witness, in a decidedly pro-Dantean and Stilnovist anthology, MS Vaticano Chigiano L VIII 305 from the 1350s, assigns the sonnet to Dante with linguistic and stylistic interference from Guido Cavalcanti's sonnet Perché non fuoro a me gli occhi dispenti. See Storey 1993, 139-56.

3. See especially Avalle [1961] 1993, 23-59, in which he outlines the geographical distribution of the manuscript traditions of Old Occitan literature and considers the implications of the geography of witnesses for editing Old Occitan lyrics. More recently Carlo Pulsoni (2004) has added nuanced considerations of the structural and linguistic implications of the geographies of the production of Old Occitan lyric anthologies in northern Italy. 
materials upon which copies are produced potentially influence formulae of transcription. Giancarlo Savino's proposal (2001) that Dante's own original transcriptional formula for the Divine Comedy, laid out in two columns in a chancery hand, established the model for fourteenth-century copies of the work seems to suggest the potential power of certain iconic works - like the Commedia or Petrarch's Rerum vulgarium fragmenta - to overcome local, material options. Consequently the variation of Boccaccio's consistent transcriptions in a Florentine context of the Commedia in a single column with ample margins would seem to reveal a significant, even authoritative (given Boccaccio's contemporary stature), departure from the material model for the Commedia. But for most other and certainly less iconic works, it would seem that the act of transcription was most often a negotiation between the preparation of a text for local reading habits and in forms familiar to local users of manuscripts and the inherent - and potentially authorial - mechanics of presentation, including visual poetics, that at times we can still glimpse in an error or problematic format, such as the extended sonnet - or sonetto rinterzato — of the thirteenth and fourteenth centuries. ${ }^{4}$

Within texts themselves, geography and mobility can be used to posit interpretative keys as well as "distance" or solidarity among readers. From the anonymous eighth-century Epistola de rebus in Oriente mirabilibus to Heinrich Bünting's 1581 Itinerarium sacrae scripturae, travel literature and mapping devoted to the "marvelous" marked the "exotic" in terms of geographical distance. ${ }^{5}$ On the other hand, books of hours were usually specifically designed for local readership knowledgeable of local saints and feasts. The same can be said for what we could call "coterie works", among them Dante's youthful Vita Nova, designed not only to reflect the local poetic culture but also to import then avant-garde trends from diverse traditions into that local culture. ${ }^{6}$ At the same time some medieval texts and even entire genres demonstrate a remarkable flexibility in their adaptability for

4. See my discussion (Storey 2003) of scribal resistance to this poetic genre as an example of the tension between poetic use and the standardizing matrices employed by the copyists of emblematic MSS such as Escorial e.III.23; Vatican Library, Barberiniano Latino 4036, and Latino 3793; and Firenze, Biblioteca Nazionale Centrale Magliabechiano Classe VI 143.

5. See especially Marcello Ciccuto's introduction to his 1994 edition and translation, as well as Bologna 1977.

6. I am grateful to Jelena Todorović for an advance reading of relevant chapters of her book manuscript, "Text in Context: Reading Cultures in Dante's Vita Nova". See as well STOREY 2005 for the interface between scribal and narrative systems in the Vita Nova. 
local performance or "use", from highly mobile and recyclable praise poetry in Old Occitan to Boccaccio's Decameron.?

Among scholarly editors, the opposition between "textual geography" and "mobile texts" has held sway since medieval copyists were given the task of transcribing vernacular works that were not "local". We know little, for example, about the late twelfth-century troubadour Raimbaut de Vaqueiras except that he was born mid-century near Orange in Provence and, like many of his fellow poet-singers, immigrated to northern Italian courts during the years leading up to the Albigensian crusades; in Raimbaut's case it was the patronage of Bonifacio I in Monferrato that drew him, probably in the 1190s, to Bonifacio's court in the Piedmont, and then to Constantinople on the fourth crusade. One of his most popular songs that circulated widely throughout Italy, Domna, tant vos ai preiada, is a bilingual debate in which a courtly Occitan troubadour attempts to win the favor of a less-than-courtly Genoese woman, who-we quickly learn - has little regard for the likes of smooth-talking singers from Provence. Geography is at the heart of this social and literary parody but also central to the construction of two languages of different social registers. The oppositional elements in the poem poke fun at the artificial language of courtly poetry, the failed seduction of the Provençal pastorela, the crass merchant culture to which the Genoese woman belongs, and the worthlessness of the Provençal singer's compliments, suggesting that long before any extant manuscript of Occitan poetry transcribed in Italy there was a savvy Italian class that enjoyed making fun of courtly rhetoric ("Jujar, to proenzalesco [. . . ] non prezo un genoì"; Singer, I wouldn't give two cents for your Provençal talk [Linskill 1964, 100-1, vv. 71-3; cf. Dionisotti and Grayson 1972, 95]).

The clash of two languages and their cultures leads the scholarly editor to several headaches: how to settle on a text written possibly for or about the Malaspina court by an Occitan poet who imitates the mercantile dialect of Genoa, that then is copied by Italian scribes? This poem, which relies so heavily upon the notion of geography and socio-economic class, quickly became a "mobile text" that was filtered through the local options of scribes less competent in one of the two languages. While there are forms reminiscent of Genoese (-ao of malaurao [21], mozo [23]; but genoi [73; a small Genoese coin] and barbarì [75; a foreigner] — both in rhyme and in the Genoese domna's speech — reveal an Occitan morphology [see

7. Old Occitan poets often recycled poems by changing the addressee in the closing verses, or the envoi or tornada. In the case of Boccaccio's Decameron, some manuscripts reveal new locations inserted perhaps by the copyists of merchants interested in personalizing the tales. 
Dionisotti and Grayson 1965, 95]), it seems that Raimbaut might have depended more generally upon a parodied dialect that didn't find its origins solely in the spoken language of contemporary Genoa. Raimbaut's most recent editor, Joseph Linskill, grapples with geographically oriented variants by relying upon the rationale that the poem's driving filter is the "provençalization" of forms in the original $(1964,98)$. Linskill's view favors an "original" by Raimbaut and discounts in theory the poem's almost exclusively Italian manuscript tradition. Three of the four anthologies (MSS Modena, Biblioteca Estense $\alpha$. R.4.4 = Da, Paris, Bibliothèque nationale de France, fr. 853 = I, and Paris, Bibliothèque nationale de France, fr. 12473 $=\mathrm{K})$ in which we find Domna, tant vos ai preiada were produced by Italian scribes; the fourth, the most "corrupt", MS Modena, Biblioteca Estense Càmpori y.N.8.4, was transcribed by a seventeenth-century French amanuensis for an Italian patron using, we believe, a thirteenth-century exemplar.

In light of these factors, I would posit that the influence and popularity of Domna, tant vos ai preiada had created a work of such mobility that local Italianizing tendencies took hold of the text to "make it its own" in spite of the poem's seemingly strict geographical features. The northern Italian reception of Domna, tant vos ai preiada records at least three local bilingual versions that give us much more useful information about the culture doing the transcribing than about Raimbaut's understanding of Genoese through his "Provençal talk".

My other example of textual geography and mobility, upon which I will focus my attention at a different level, is far more daunting, particularly because the work was not only popular but also extraordinary in its textual swings between fixity and variation. The difficulty of the variations in the ordering of its components was due in no small part to its author, Francesco Petrarca, who tinkered not only with microscopic variants but also with the order of the 366 poems of his Rerum vulgarium fragmenta (Rvf) until, it would seem, his dying day.

Petrarch's own fair copy turned service manuscript and, for a good number of poems, an experimental work zone, MS Vatican Library, Latino 3195, is an uncirculated collection of loose gatherings at his death. This partially holograph codex tells many tales of mobile texts moving in and out and around the Fragmenta. ${ }^{8}$ It is an excellent example of the way that tex-

8. See Storey 2004, 133-4. Beyond the lexical variants and diverse scribal layouts of fourteenth- and early fifteenth-century MSS produced from the Veneto to Tuscany, the textual mobility of Petrarch's Fragmenta takes the shape not only of the author's revised order of some of the compositions but also the author's own variants at various stages of the evolution of the macrotext. See, for example, Belloni 2004, Pulsoni 2007, Pulsoni and Cursi 2009, and Rossi 2010, 
tual mobility creates fault lines in works whose landscape depends upon what seems to be a textual cohesion created by clusters of poems linked by semantics, prosody, themes, geography, and chronology.

It was most likely in 1369 that Petrarch was confident enough that the Fragmenta were completed, thanks in large part to his copyist Giovanni Malpaghini, that he commissioned the rubrication and initials to be added to the manuscript to solidify its "fair copy" status. ${ }^{9}$ Once this copy was back in his hands, however, Petrarch changed his mind about - among other things _ poem 121, the ballata Donna mi vene spesso ne la mente, on c. $26 r$.

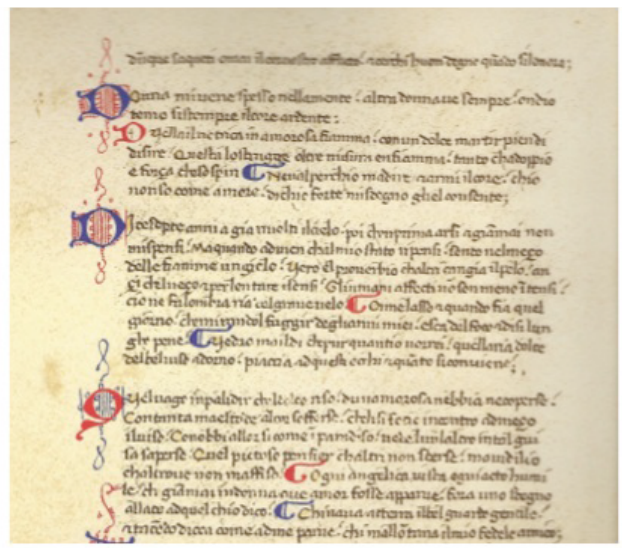

Plate 1. Vatican Library Chigiano L v 176, c. 63v detail.

who examine the degrees to which Petrarch's earlier authorial variants appear in significant copies heretofore relatively unstudied because of scholars' reliance upon WILKINs 1951 and the poet's holograph (MS Vatican Latino 3195). For additional, microscopic levels of variantistica, especially for layout, punctuation, and majuscules, as in the case of MS Laurenziano Segniano 1, see Stor Ey 2004, 148-65.

9. Much of the chronology of the construction ("making") of Petrarch's Rerum vulgarium fragmenta was conjectured by Wilkins (1951) from the poet's letters as well as the reports of other scholars on the changes in pen and ink that they surmised from direct examination of Vatican Latino 3195. Wilkins himself never had occasion to consult directly the MSS in question, including the partial holograph, except for some MSS found in American libraries. Recently scholars have begun to demonstrate the instability of Wilkins' method and conjectures (see Del Puppo and Storey 2003, Zamponi 2004, Pulsoni 2009) that resulted in nine different forms of the collection as it evolved from its early ideation to the poet's death in 1374. For example, Stefano Zamponi (2004) has radically revised Wilkins' calculations of the speed at which Malpaghini worked. Del Puppo and Storey (2003) examine especially the layers of probability upon which some of Wilkins' most pivotal conjectures turn. 
Boccaccio's earlier transcription of Petrarch's Fragmentorum liber (MS Vatican, Chigiano L v 176) reveals that in 1362 the ballata Donna was situated between the sonnet Quelle pietose rime in ch'io m'accorsi (Rvf 120) and the anniversary sonnet Dicesette anni à già rivolto il cielo (Rvf 122). The evidence of the ballata's presence in the author's partial holograph (Vaticano Latino 3195, c. 26r) rests on traces of the ascender of the gothic 'D',

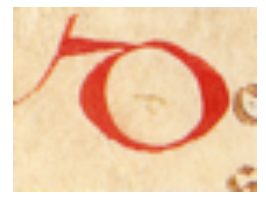

that started the first verse of Donna mi vene spesso ne la mente and the guide letter ' $\mathrm{d}$ ' inside the converted $\mathrm{O}$ on c. $26 r$, visible to the naked eye but clearer under magnification:

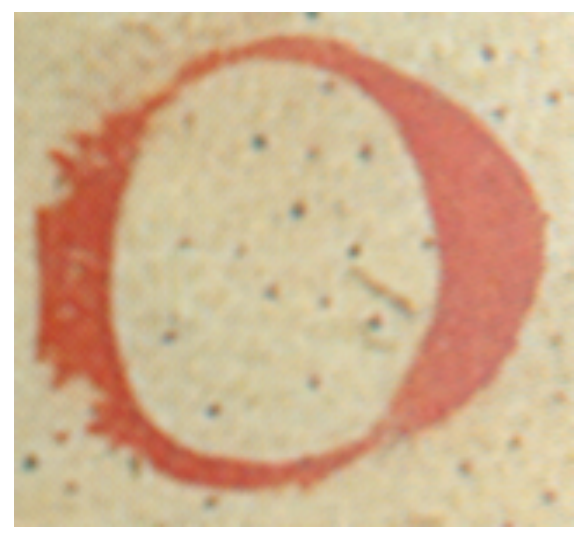

We do not know exactly when, but Petrarch has the ballata Donna mi vene erased and inserts in his own hand on the six transcriptional lines at his disposal the madrigal Or vedi, Amor, che giovenetta donna. The copyist of our model exemplar of the poem (Plate 2), in black and white taken from MS Laurenziano 41.17 (between 1370 and 1400), follows carefully the layout for Petrarch's visual-poetic forms, including the ballata. ${ }^{10}$ This copy allows us to see the evolution of the erasure of the ballata's six transcrip-

10. For a detailed analysis of the MS and the copyist of Morgan M. 502's use of Petrarch's transcriptional strategies for the genres of the Fragmenta, see STOREY 2006. 


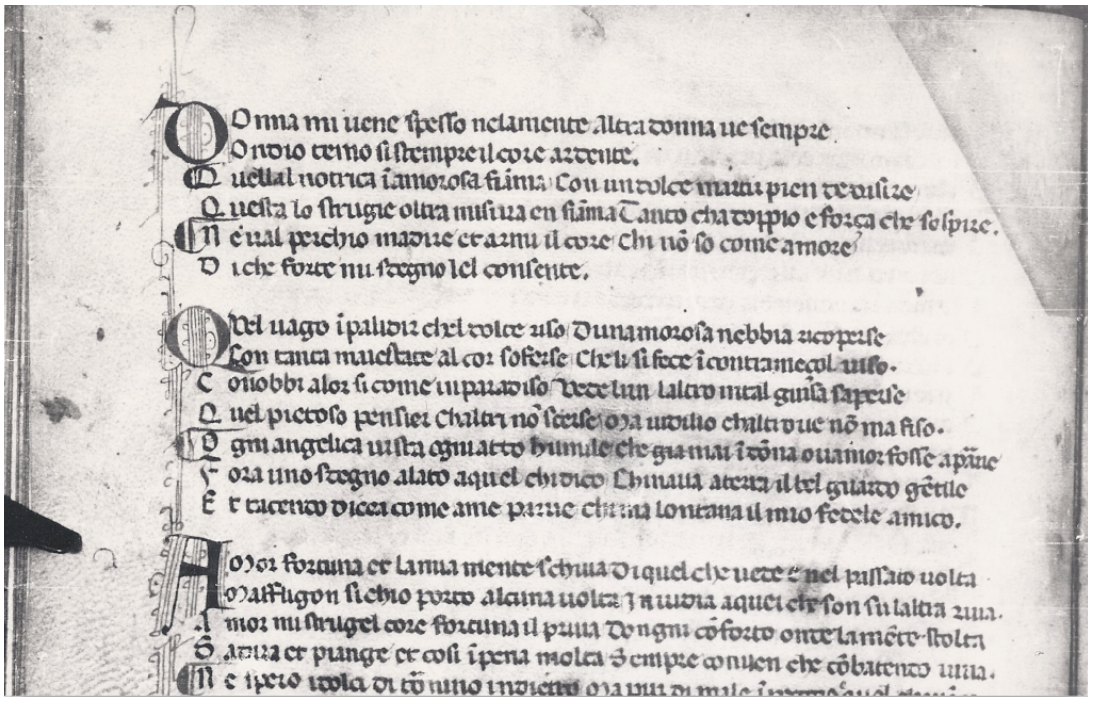

Plate 2. Biblioteca Laurenziana 14.17, c. $25 v$ detail.

tional lines and the alteration of the ballata's first letter to form the first letter of the madrigal that would replace it. Petrarch recycles the red majuscule gothic $\mathrm{D}$ by erasing the ascender to leave the rounded portion of the $\mathrm{D}$ which has now become the red majuscule $\mathrm{O}$ of Or vedi, Amor.

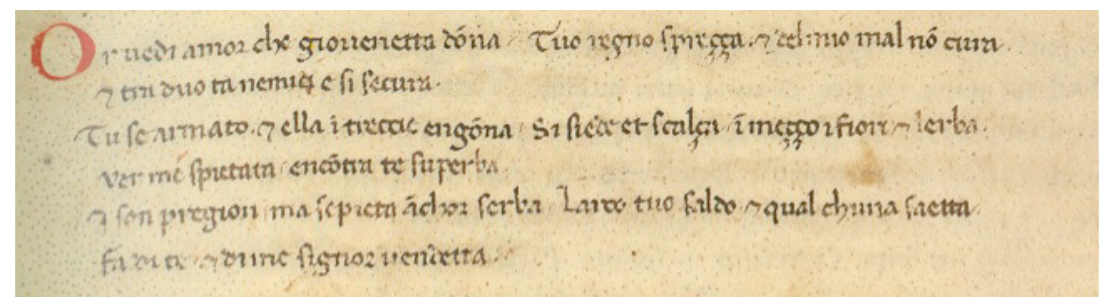

Plate 3. Vatican Library Latino 3195, c. 26r detail.

Noted by Wilkins (1951, 112-4) this episode of Petrarch's reordering within the Fragmenta is relatively well known to Petrarch scholars familiar with the history of his partial holograph manuscript, Vaticano Latino 3195. To most readers today, however, the erasure and alteration mean simply the elimination of the ballata Donna mi vene from the collection and the shift of Or vedi, Amor from where we believe Petrarch took the madrigal 
- 119 Una donna puì bella assai che 'l sole

- 120 Quelle pietose rime in ch'io m'accorsi

- 121 J mma mi vene गpeगd me ta mente

- $\rightarrow$ Or vedi Amor; che giovenetta donna

- 122 Dicesette anni à già rivolto u elo

242 Mira quel colle

[?]Or vedi Amor

243 Fresco, ombroso, fiorito et verde colle (243)

Plate 4. Rvf 119-122 [242-*-243].

(from between the sonnets Mira quel colle, o stanco mio cor vago [Rvf 242] and Fresco, ombroso, fiorito et verde colle [Rvf 243]) to its new position at the top of c. $26 r{ }^{11}$ But like most palimpsests, something remains of the ballata in the Fragmenta beyond the round body of the recycled D. In truth this change after the final rubrication of the fair copy portion of the manuscript will create a significant textual fracture in the macrotext's construction that will leave subsequent copyists and fifteenth-century editors and compositors in doubt as to the treatment not just of the ballata and the madrigal that replaces it, but even about what poems actually belong to this section of the Fragmenta.

Throughout the early manuscript tradition of the late fourteenth and the early fifteenth century, the area of Rvf 121 will for any number of reasons become one of the favorite places of copyists to insert poems probably unintended for the Fragmenta, often known as Petrarch's rime disperse, his scattered or uncollected lyric poems. ${ }^{12}$ This weakness invariably occurs after the indivisible unit of two poems associated with Petrarch's correspondent Antonio Beccari da Ferrara: Rvf 119 (the canzone Una donna più bella assai che 'l sole) and Rvf 120 (the sonnet Quelle pietose rime in ch'io m'accorsi). In many of the most reliable early manuscripts of the Fragmenta, the ballata Donna mi vene, expunged from Petrarch's working copy (Vaticano Latino 3195, c. 26r), floats in the area of poem 121 even when

11. See, for example MSS Laurenziano 41.17, discussed here below, Riccardiano 1088, and, perhaps determinative, Casanatense 924.

12. Angelo Solerti's edition of the Rime Disperse (1909) was reissued in facsimile in 1997 with an essential critical and editorial update by Paola Vecchi Galli; see Solerti [1909] 1997, 323-410. 
the madrigal, Or vedi, Amor has taken up residence in or near the same position. ${ }^{13}$

We know that Petrarch had already sanctioned and circulated at least one version of his collection in which Donna mi vene rested between Rvf 120 (Quelle pietose rime in ch'io m'accorsi) and Ruf 122 (Dicesette anni à già rivolto il cielo), that is in the version copied by Giovanni Boccaccio in the early 1360s (MS Chigiano L v 176, c. 63v). After Petrarch's death in 1374, in numerous early manuscripts (such as Trivulziano 1091, Riccardiano 1088, and Morgan Library M502), Donna mi vene appears between or in the vicinity of 120 and 122. In other cases, when Or vedi, Amor is transcribed as poem 121, Donna tends to find its place near the anniversary sonnet 122. Modern scholars usually see - and for the most part dismiss - these variants through the prism of the partial holograph and partial fair copy of MS Latino 3195. But the local context, including Petrarch's authorial and scribal habits, adds a dimension left unconsidered by those who would fetishize the holograph. First of all, only a portion of Latino 3195 can be considered a fair copy of Petrarch's intentions produced for the most part by Petrarch's scribe, Giovanni Malpaghini, with some microscopic corrections in the poet's own hand. Even when on the few occasions that Petrarch entered poems completely in his own hand in the fair copy sections, such as Geri, quando talor meco s'adira (Rvf 179, Latino 3195, c. 37r), he still returns later to the codex not just to correct errors but to erase and revise, in some cases extensively. And once Petrarch abandons the idea of maintaining the manuscript's fair copy form, it becomes an experimental work site.

Key to understanding the mouvance of Donna mi vene and Or vedi, Amor is Petrarch's "local practice" of authorizing and releasing his works not through his own autograph copies but in fair copies produced by authorized copyists. While MS Latino 3195 was in its early form, I believe, originally intended to circulate as a fair copy of the Fragmenta, it in fact never circulated. We certainly see evidence of readings unique to Latino 3195 in manuscripts such as Laurenziano Segniano 1, Laurenziano 41.10, and Morgan M. 502, especially these manuscripts' dutiful adherence to the visual-poetic transcriptional formulae followed by Petrarch. But, it is more than likely that subsequent copies overseen by either of Petrarch's heirs, Francescuolo da Brossano or Lombardo della Seta, used a fair copy of an earlier form of the holograph. ${ }^{14}$ The unfinished nature of Petrarch's holograph would have

13. See, for example, MSS Cologny, Bodmer 131 and Vatican, Barberiano Latino 3954.

14. As Gino Belloni has carefully reasoned (2004, 78-80), Petrarch's unfinished holograph was never treated as part of the poet's library, portions of which were to have gone to Francesco il Carrarese, the Lord of Padova and, since 1356, 
made it unsuitable as an exemplar. This state of potential textual uncertainty literally about what was in the Fragmenta and its definitive order led to what would become virtually a critical industry of conjecture about authorized redactions of the work. ${ }^{15}$

MS Morgan M502, probably produced shortly after Petrarch's death in 1374 from an authoritative fair copy transcribed before many of the poet's emendations were entered into Latino 3195, tells part of the story of the perception of the uncertain textual landscape of the Fragmenta in the 1370s. As we see on c. 21v, the copyist of M502 works carefully from the

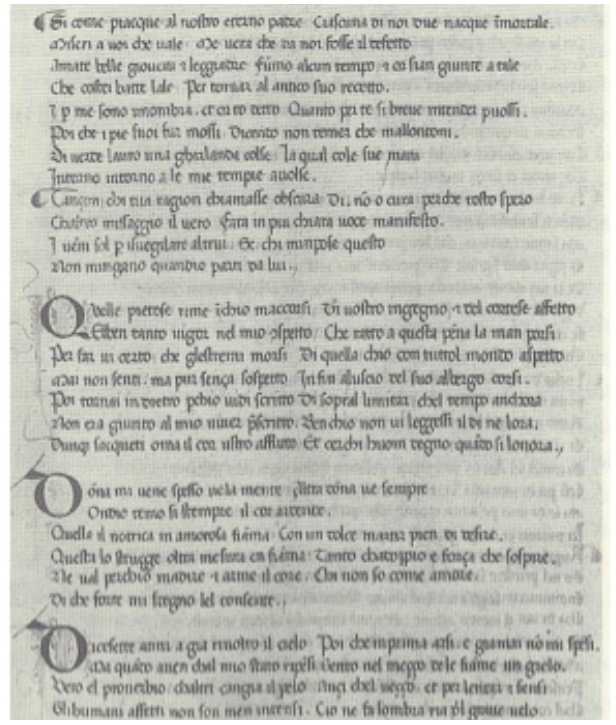

Plate 5. Morgan Library M.502, c. 21r.

antegraph with no interruption in ink, ductus, or form, following with equal accuracy the diversified layouts respectively for the canzone (Rvf 119),

the imperial vicar of Charles IV. While damaged and fragmentary, Laurenziano Segniano 1, from the early fifteenth century, seems to be one of the few codices taken at least partially from Petrarch's copy (see Storey 2004, 149). Only in the early 1470 s a still anonymous editor sets the text of the Paduan Valdezoco edition of 1472 using a manuscript he has found at the home of the Santasofia family, Petrarch's partial holograph.

15. The twentieth-century hallmark of that industry is, of course, WiLKIns 1951. But the industry's conjectural matrices are well entrenched and, in some sectors, taken for granted in the critical discourse of the nine forms of Petrarch's Fragmenta. For a review of the history of the factualization of these conjectures, see Barolini 2007. 
the sonnet ( $R v f 120$ and 122) and the ballata (here Rvf 121). While throughout M502 we find traces of local and regional linguistic forms, the formal and material fixity of the lectiones of each poem seems to guarantee the authenticity of M502's antegraph. ${ }^{16}$ In fact, the accuracy and clarity of vv. 103 and 105 seems to demonstrate that the copyist took his text from a fair copy exemplar that was not the poet's partial holograph, which at c. $25 \mathrm{v}$ reveals a difficult reading over an erasure at the beginning of the two verses, especially of "Diuerde lauro":

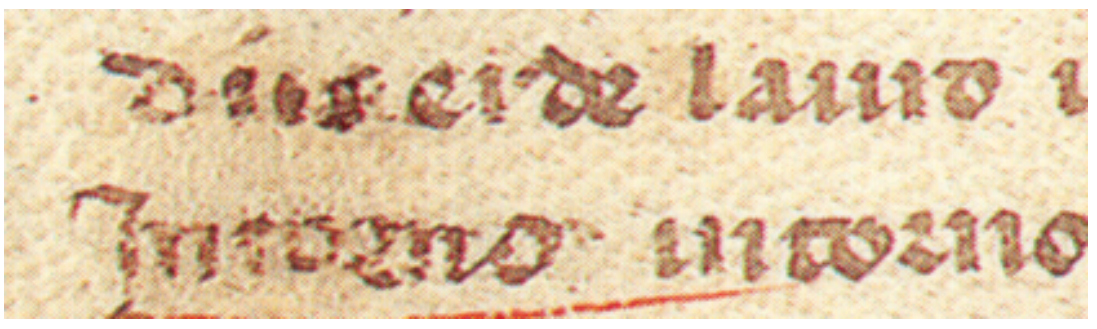

It is then noteworthy that the madrigal that would replace the ballata Donna mi vene, Or vedi, Amor now has moved from its earlier position - as we see in MS Laurenziano 41.17, c. 46r (see Plate 6) - between the sonnets Mira quel colle (Rvf 242) and Fresco, ombroso, fiorito et verde colle (Rvf 243)

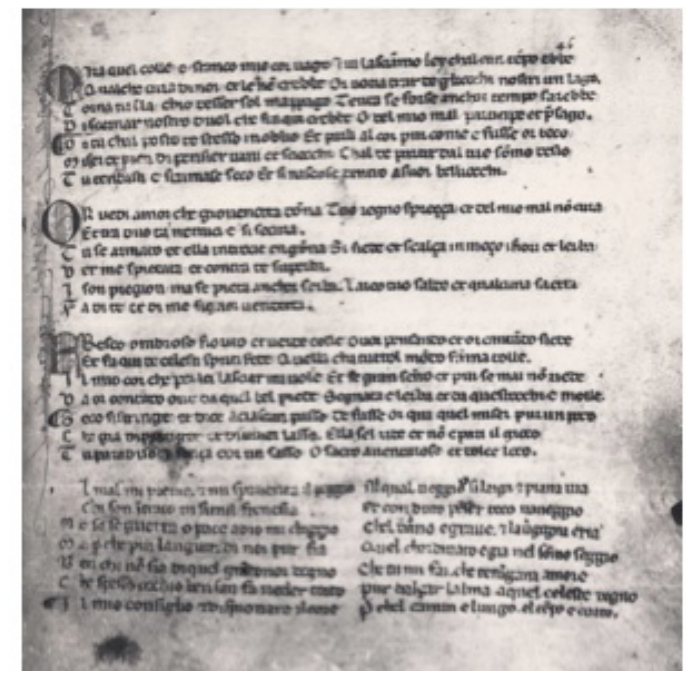

Plate 6. Biblioteca Laurenziana 41.17, c. 46r.

16. For the regional forms of MS Morgan M502, see Store y 2006, 495-6. On c. 21v we note, for example, the copyist's recetto for ricetto (Rvf 119,98$)$. 
to a unique position between the canzone Di pensier in pensier di monte in monte (Rvf 129) and the sonnet Poi che 'l camin m'è chiuso di mercede (Rvf 130 ), changing with it the interpretative values of these contiguous poems. On c. 25v of M502 the madrigal Or vedi, Amor has been transcribed with equal accuracy at the top of the charta. It has not simply been inserted from a different exemplar to fill space, as several fifteenth-century copyists handled Donna mi vene, seemingly uncertain about where to put the ballata but knowing that it should go somewhere in the collection. ${ }^{17} \mathrm{We}$ should note that in spite of their mobility within the order of the poems of the Fragmenta and - implicitly - in diverse interpretative contexts, the texts themselves show no substantive lexical variants.

The late fourteenth-century MS Bodmer 131 demonstrates how Petrarch's late revision within the larger context of his lyric production in the vernacular creates a textual mobility within the Fragmenta that opens the work to local editorial innovation. On c. 54v, after Rvf 120, Quelle pietose rime, the copyist inserts not one but six sonnets from Petrarch's uncollected lyric poems before copying the revised Rvf 121, Or vedi, Amor, Rvf 122, Diciasettanni, and finally Donna mi vene spesso ne la mente on cc. $\underline{56 r}$ and $\underline{56 v}$. With the end of the gathering at c. 55v, one could even imagine that in a pinch four of the sonnets might have been used to fill unused space at the end of the quire. But the catchword "Conte" on c. $55 v$ and the continuation of two "uncollected" sonnets Conte Riciardo, quanto più ripenso and Ingegno usato a le question profonde before the appearance of $\mathrm{Or}$ vedi, Amor at the bottom of the charta leave little doubt that the extraordinary six-sonnet interpolation is part of the program that the Bodmer copyist had before him in the antegraph from which he was working (see cc. $\underline{56 r}$ and $\underline{56 v}$ ). This is the only extant manuscript in which we see this degree of mobility and this extensive a use of Petrarch's uncollected lyric poems within a form of the work we can still recognize as the Rerum vulgarium fragmenta. But the intervention is emblematic of the extent to which mobile texts are drawn to textual openings such as between and around poems 120 and 122 .

17. See, for example, MSS Milano, Trivulziano 904 and Vatican Ottoboniano Latino 2998, both fifteenth-century deluxe codices, in which we find Donna mi vene inserted immediately before the final poem of the Fragmenta: Vergine bella, che, di sol vestita (Rvf 366). In the case of MS Ottoboniano Latino 2998, Donna mi vene is copied twice, once on c. 103v after Rvf 119 (Una donna più bella assai che 'l sole) and, for good measure, again on c. $190 v$ before Rvf 366. 


\section{c. $54 v$ :}

121 Quelle piatose rime in chio macorsi Rvf 120

122 Per che l'eterno moto sopraditto

c. $55 r$ :

123 Quantera amata daconcio cidipe

c. $55 \mathrm{v}$ :

124 O besstiuola che gia fusti in pregio

125 Si come da la madre difetonte

\{catchword: Conte\}

c. $56 r$ :

126 Conte Riciardo quanto piu ripenso

127 Ingiegnio usato ale quesstion profonde

128 Or uedi amor che giouenetta donna Rvf 121 [rev]

c. $56 \mathrm{v}$ :

129 Diciascettanni agia ruolto il cielo Rvf 122

130 Jonna me viene spesso nellamente Rvf 121

c. $57 r$ :

131 Quel uagho empallidir chel Jolcie riso Rvf 123

Plate 7. Bodmer Library, MS 131, cc. 54v-57r.

Petrarch's mobilization of Or vedi, Amor can only change so much of the Bodmer copyist's sense of the work's textual geography. The mobility of Or vedi, Amor weakens the cohesiveness of the transition from Rvf 120 to 121 and 122, but it does not suppress the former 121, the ballata Donna mi vene spesso ne la mente; rather - as an echo of a former version - this same mobility is extended by the Bodmer scribe to what becomes in Petrarch's own copy a palimpsest. In the early and uncertain circulation of the Fragmenta after Petrarch's death, Donna often re-surfaces to coexist in the lyric narrative with Or vedi, Amor instead of ceding to it.

If the ancient manuscript tradition of Donna mi vene spesso ne la mente demonstrates the mobility of a component part of the Fragmenta without significant lexical and syntactic variation, the ballata's modern editorial treatment reveals the power of its continued palimpsestic presence in the iconic Fragmenta. While modern editors now classify Donna mi vene as one 
of Petrarch's uncollected poems, or rime disperse, the ballata has a special status as a work once admitted into the Fragmenta but then ultimately - literally after Petrarch's own copy Latino 3195 was rubricated - rejected. The reasons cited by modern editors for its elimination from the collection usually note - in an unusually literal vein - Donna's introduction of a second love interest: "Donna mi vene spesso ne la mente; / altra donna v'è sempre" (vv. 1-2: One woman comes often to my mind / another is always there). Dante Bianchi $(1940,28-33)$ was among the first to suggest that the two women are not flesh and blood but allegories respectively for Virtue and Fame (Glory), with clear links to the allegorical theme of the preceding canzone Una donna più bella assai che 'l sole (Rvf 119). According to this interpretation, the ballata would have been rejected not because of a second woman but because of its repetition of the allegory of poetic glory in Una donna (BiAnchi 1940, 33). Rosanna Bettarini sees in the ballata a Dantean allegory that reduces the essential allegory of the already mentioned Rvf 119 and is reminiscent of the sestina Amor, tu vedi ben che questa donna and of Dante's famous canzone Così nel mio parlar voglio esser aspro (2005, 1: 564-5).

These interpretations are instructive in their reliance upon the formal and thematic contexts of the Fragmenta, conjecturing thematic and stylistic principles of exclusion to explain the rejection of Donna mi vene and some of Petrarch's compilational strategies of the Fragmenta. Even among modern editors of Petrarch's uncollected lyrics the ballata seems to require special treatment. Angelo Solerti places it first among forty uncollected poems and fragments he attributes to Petrarch due to the fact that it was once included in the Fragmenta ([1909] 1997, 71). More recently, Laura Paolino inserts it into her collection of Rime estravaganti as n. 18 (1996, 729-32), noting however that the only way to date the composition of the ballata is through the possible dates of composition of its once companion poems in the Fragmenta (730). One of the most discussed poems by Petrarch not included in the Fragmenta seems due, ultimately, to the very influence of the ballata's mobility, first in early manuscripts of Petrarch's iconic book and then in the ultimate mobility of its rejection from the Fragmenta, to which it is still editorially and interpretatively tied. It at once hovers in and behind the scenes of the composition of the Fragmenta and, in its exclusion from the Fragmenta, partially explains the work's principles of compilatio. Despite its final "official" rejection in Petrarch's own hand, Donna mi vene spesso ne la mente is a poem that is inexorably linked to the Fragmenta. It influences the interpretation of the madrigal that replaced it and, as we have seen, the poems that once accompanied it in the collection. 
The complex history of Donna mi vene spesso ne la mente as a resistant, mobile text within the Rerum vulgarium fragmenta and the socialperformative contexts and textual condition of Domna, tant vos ai preiada exemplify editorial and critical circumstances in which we are forced to rethink the roles and the relationship of textual mobility and its supposedly oppositional category of textual fixity. While we ask our editions to give us definitive forms, it is difficult to ignore the multiple interpretative layers of textual movement, either through the transmission of copies or authorial emendation and reordering. These are variants that belong more to the palimpsest than to the critical apparatus. While not definitively part of the text, they still help define it.

Indiana University-Bloomington

\section{Works Cited}

Avalle, D’Arco Silvio. [1961] 1993. I manoscritti della letteratura in lingua d'oc, edited by Lino Leonardi. 2d ed. Torino: Einaudi.

Barolini, Teodolinda. 2007. "Petrarch at the Crossroads of Hermeneutics and Philology: Editorial Lapses, Narrative Impositions, and the Wilkins' Doctrine of the Nine Forms of the Rerum vulgarium fragmenta". Petrarch and the Textual Origins of Interpretation, edited by Teodolinda Barolini and H. Wayne Storey, 21-44. LeidenBoston: Brill.

Belloni, Gino. 2004. "Nota sulla storia del Vat. Lat. 3195". In Francesco Petrarca, Rerum vulgarium fragmenta, Codice Vat. Lat. 3195. Commentario all'edizione in facsimile, edited by Gino Belloni, Furio Brugnolo, H. Wayne Storey, and Stefano Zamponi, 73-104. Roma-Padova: Antenore.

Bettarini, Rosanna, ed. 2005. Francesco Petrarca. Canzoniere / Rerum vulgarium fragmenta. 2 vols. Torino: Einaudi.

Bianchi, Dante. 1940. "Intorno alle 'Rime disperse' del Petrarca. Poesie e abbozzi tratti da carte autografe". Bollettino storico pavese 3.2: 25-72.

Bologna, Corrado. 1977. Liber monstrorum de diversis generibus. Milano: Bompiani.

Ciccuto, Marcello, ed. 1994. Le meraviglie dell'Oriente. De rebus in Oriente mirabilibus. Pisa: Edizioni ets.

Del Puppo, Dario, and H. Wayne Storey. 2003. "Wilkins e la formazione del canzoniere di Petrarca". Italica 80: 495-512.

Dionisotti, Carlo, and Cecil Grayson, eds. [1965] 1972. Early Italian Texts. $2 d$ ed. Oxford: Blackwell.

Linskill, Joseph, ed. 1964. The Poems of the Troubadour Raimbaut de Vaqueiras. The Hague: Mouton.

Paolino, Laura, ed. 1996. Frammenti e Rime estravaganti. In Francesco Petrarca. Trionfi, Rime estravaganti, Codice degli abbozzi, pp. 627-754. Milano: Mondadori. 
Pulsoni, Carlo. 2004. "Appunti per una descrizione storico-geografica della tradizione manoscritta trobadorica". Critica del Testo 7: 357-90.

. 2007. "Appunti sul ms. E 63 della Biblioteca Augusta di Perugia”. L'Ellisse 2: 29-99.

2009. "Il metodo di lavoro di Wilkins e la tradizione manoscritta dei Rerum vulgarium fragmenta". Giornale italiano di filologia 61: 257-68.

Pulsoni, Carlo, and Marco Cursi. 2009. "Sulla tradizione antica dei 'Rerum vulgarium fragmenta': un gemello del Laurenziano XLI 10 (Paris, Bibliothèque Nationale, It. 551)". Studi di filologia italiana 67: 91-114.

Rossi, Michele. 2010. "Il MS. 4 della Biblioteca del Seminario Vescovile di Padova". Studi Petrarcheschi, n.s. 23: 101-59.

SAvino, Giancarlo. 2001. "L'autografo virtuale della Commedia". "Per correr miglior acque": Bilanci e prospettive degli studi danteschi alle soglie del nuovo millennio, 1099_ 1110. Roma: Salerno.

ScAse, Wendy, ed. 2007. "Introduction”. Essays in Manuscript Geography: Vernacular Manuscripts of the English West Midlands from the Conquest to the Sixteenth Century, 1-9. Turnhout: Brepols.

Solerti, Angelo, ed. [1909] 1997. Rime disperse di Francesco Petrarca o a lui attribuite. Firenze: Le Lettere.

Store y, H. Wayne. 1993. Transcription and Visual Poetics in the Early Italian Lyric. New York: Garland.

2003. "Early Editorial Forms of Dante's Lyrics". Dante for the New Millennium, edited by Teodolinda Barolini and Wayne Storey, pp. 16-43. New York: Fordham University Press.

- 2004. "All'interno della poetica grafico-visiva di Petrarca". In Francesco Petrarca, Rerum vulgarium fragmenta, Codice Vat. Lat. 3195. Commentario all'edizione in fac-simile, edited by Gino Belloni, Furio Brugnolo, H. Wayne Storey, and Stefano Zamponi, 131-71. Roma-Padova: Antenore.

- 2005. "Following Instructions: Remaking Dante's Vita Nova in the Fourteenth Century". Medieval Constructions in Gender and Identity: Essays in Honor of Joan M. Ferrante, edited by Teodolinda Barolini, 117-32. Tempe, Arizona: Medieval and Renaissance Texts and Studies.

2006. "Il codice Pierpont Morgan M. 502 e i suoi rapporti con lo scrittoio padovano di Petrarca". In La cultura volgare padovana nell'età del Petrarca, edited by Furio Brugnolo and Zeno Verlato, 487-504. Padova: Poligrafo.

Swan, Mary. 2007. "Mobile Libraries: Old English Manuscript Production in Worcester and the West Midlands, 1090-1215”. In Scase 2007, $29-42$.

Wilkins, Ernest H. 1951. The Making of the Canzoniere and Other Petrarchan Studies. Rome: Edizioni di Storia e Letteratura.

Zamponi, Stefano. 2004. "Il libro del Canzoniere: Modelli, strutture, funzioni". In Francesco Petrarca, Rerum vulgarium fragmenta, Codice Vat. Lat. 3195. Commentario all'edizione in fac-simile, edited by Gino Belloni, Furio Brugnolo, H. Wayne Storey, and Stefano Zamponi, 13-72. Roma-Padova: Antenore. 